\title{
Formulasi Dan Uji Aktivitas Anti Bakteri Masker Gel Peel-Off Ekstrak Daun Pacar Air (Impatiens balsamina linn.) Dengan Kombinasi Basis PVA dan HPMC
}

\author{
Sony Andika Saputra ${ }^{1}$, Munifatul Lailiyah ${ }^{2}$, Adella Erivina ${ }^{3}$ \\ ${ }^{1}$ Fakultas Sains, Teknologi dan Analisis Institut Ilmu Kesehatan Bhakti Wiyata Kediri \\ ${ }^{2}$ Fakultas Farmasi, Institut Ilmu Kesehatan Bhakti Wiyata Kediri \\ ${ }^{3}$ Fakultas Farmasi, Institut Ilmu Kesehatan Bhakti Wiyata Kediri \\ Email Korespondensi : sony.saputra@iik.ac.id
}

\begin{abstract}
ABSTRAK
Pacar air (Impatiens balsamina Linn.) mengandung senyawa kumarin, kuinon, flavonoid, steroid, triterpenoid, fenolik dan saponin, yang mempunyai aktivitas anti bakteri Staphylococus Aureus. Tujuan dari penelitian ini adalah untuk mengetahui pengaruh kombinasi basis HPMC dan PVP terhadap karakteristik gel dan uji aktivitas anti bakteri terhadap Staphylococus Aureus. Metode penelitian ini adalah formulasi masker gel peel-off ekstrak daun pacar air (Impatiens balsamina Linn.) dengan menggunakan kombinasi basis PVA dan HPMC F1 (1:2,6), F2 (1:3), F3 (1:3,5). Formulasi yang didapat di uji karakteristik gel meliputi uji organoleptis, viskositas, daya lekat, waktu mengering, daya sebar, Ph. Serta dilakukan dengan pengujian aktivitas antibakteri Staphylococus Aureus. Berdasarkan hasil penelitian F3 menghasilkan karakteristik masker gel pell-of dengan $\mathrm{pH}$ yang sesuai syarat 5,2 $\pm 0,10$, daya sebar $6,85 \pm 0,13$, waktu mengering yang paling cepat 21,68 $\pm 0,33$ dan aktivitas anti bakteri paling baik. Berdasarkan statistik semua formula menghasilkan perbedaaan aktivitas antibakteri yang signifikan.
\end{abstract}

Kata kunci: Formulasi, Gel-pell off, Ekstrak Pacar air 


\section{ABSTRACT}

Impatiens balsamina Linn Contains the composition of coumarins, quinones, flavonoids, steroids, triterpenoids, phenolics and saponins, which contain anti-bacterial activity Staphylococus Aureus. The purpose of this study was to study the combination of HPMC and PVP on the characteristics of the gel and test the anti-bacterial activity against Staphylococus Aureus. The method of this research is the formulation of peel-off gel mask of girlfriend water leaf extract (Impatiens balsamina Linn.) By using a combination of PVA and HPMC F1 (1: 2.6), F2 (1: 3), F3 (1: 3.5 ) The formulations obtained were tested for characteristics using organoleptic, viscosity, adhesion, drying time, dispersion power, Ph. And carried out by testing the antibacterial activity of Staphylococus Aureus. Based on the results of the F3 study, the characteristics of gel pell-of masks with the appropriate $\mathrm{pH}$ requirements were $5.2 \pm 0.10$, the dispersion power was $6.85 \pm 0.13$, the fastest drying time was $21.68 \pm 0.33$ and anti-bacterial activity the best. Based on statistics, all formulas produce significant differences in antibacterial activity.

Keywords : Formulation, Gel-pell off, Extract pacar air

\section{PENDAHULUAN}

Jerawat atau acne vulgaris adalah kelainan berupa peradangan pada lapisan pilosebaseus yang disertai penyumbatan dan penimbunan bahan keratin yang dipicu oleh bakteri Staphylococcus aureus (Arista et al., 2013). Salah satu tumbuhan yang menarik untuk diteliti adalah pacar air (Impatiens balsamina Linn.). Secara tradisional masyarakat memanfaatkan pacar air dengan cara direbus dan digiling untuk dioleskan pada bagian tubuh yang terinfeksibakteri (Panichayupakaranant, 2001).

Pada penelitian yang dilakukan oleh Adfa (2008) menyatakan ekstrak daun pacar air mengandung senyawa kumarin, kuinon, flavonoid, steroid, triterpenoid, fenolik dan saponin. Naftakuinon memiliki beberapa mekanisme yakni menonaktifkan adhesin dan enzim mikroba, serta mengikat asam amino secara irreversible (Ismarani et al., 2014).

Sediaan gel seperti masker gel peeloff yang mempunyai beberapa keuntungan diantaranya penggunaan yang mudah, mudah dibersihkan tanpa dibilas dan dapat diangkat atau dilepaskan seperti membran plastik (Andaryekti et all., 2015). Bentuk sediaan gel lebih baik digunakan pada pengobatan jerawat dari pada bentuk sediaan krim karena sediaan gel dengan pelarut yang polar lebih mudah dibersihkan dari permukaan kulit setelah pemakaian dan tidak mengandung minyak yang dapat meningkatkan keparahan jerawat (Anggraini et al., 2013).

Kualitas fisik masker wajah gel peel-off dipengaruhi oleh formulasi bahan yang digunakan. Sebagai pembentuk lapisan film masker wajah gel peel-off dapat digunakan PVA. PVA tidak menimbulkan iritasi pada kulit dan mata jika pada konsentrasi kurang dari $10 \%$ 
dan biasanya dalam kosmetik digunakan PVA dengan konsentrasi sampai 7\% (Abu baker, 2009). Sebagai basis dan peningkat viskositas dapat digunakan HPMC dengan rentang konsentrasi 2-4\% (Rowe et al., 2006).

Berdasakan uraian tersebut, tujuan dalam formulasi ini adalah untuk mengetahui pengaruh kombinasi basis PVA dan HPMC terhadap karakteristik sediaan masker gel peel-off ekstrak daun pacar air (Impatiens balsamina Linn.) serta aktivitas antibakterinya terhadap bakteri Staphylococcus aureus.

\section{METODE PENELITIAN}

\section{Alat dan Bahan}

Alat yang digunakan dalam penelitian ini adalah timbangan analitik (HX-T), kertas perkamen, oven (DHG-9030), mortir dan stemper, cawan porselen, beaker glass (wardana), gelas ukur (iwaki), sudip, sendok tanduk, batang pengaduk, $\mathrm{pH}$ meter (the tester family), autoclave, bunsen, spatel, catton swab, erlenmeyer (pyrex), viskometer dan corong (herma).

Bahan yang digunakan ekstrak daun pacar air (Impatiens balsamina Linn) ekstrak daun pacar air (Impatiens balsamina Linn), PVA, HPMC, propilenglikol, methyl paraben, propil paraben, TEA, Aquadest, MHA dan NB

\section{Prosedur Kerja}

\section{a. Persiapan Sampel}

Sampel yang digunakan dalam penelitian ini adalah daun pacar air (Impatiens balsamina Linn) yang diperoleh dari Nganjuk, Jawa Timur. 500 gram serbuk simplisia diekstraksi menggunakan pelarut etanol 96\% sebanyak 3,5 L. kemudian diekstraksi selama 5 hari.

\section{b. Formulasi Masker Gel Peel-Off Ekstrak Daun Pacar Air (Impatiens balsamina L.)}

PVA dimasukkan kedalam mortir yang berisi aquadest suhu $90^{\circ} \mathrm{C}$ diaduk konstan hingga mengembang dan homogen (A). HPMC dimasukkan ke dalam motir yang berisi aquadest suhu $90^{\circ} \mathrm{C}$ ditunggu hingga mengembang dan digerus konstan hingga terbentuk masa gel (B). Propilenglikol ditimbang dalam gelas beker. Setelah A dan B mengembang sempurna campurkan mortir A kedalam mortir B secara perlahan dengan pengadukan konstan hingga keduanya tercampur sempurna. Masukkan campuran propilenglikol aduk hingga homogen. Ditimbang TEA dan masukan ke dalam mortir lalu digerus ad homogen .Ditimbang ekstrak dilarutkan dengan aqudest ad larut lalu dimasukkan dalam mortir gerus ad homogen.

\section{Evaluasi Karakteristik}

\section{Pengamatan Organoleptis}

Analisis organoleptis dilakukan dengan mengamati perubahan bentuk, bau, warna dan tekstur sediaan masker gel peel-off ekstrak daun pacar air (Impatiens balsamina Linn).

\section{Uji Homogenitas}

Sebanyak 0,1 gram gel dioleskan pada kaca objek. Kemudian dikatupkan dengan kaca objek yang lainnya dan dilihat apakah basis tersebut homogen dan permukaannya halus merata. Dengan 
syarat homogen tidak boleh mengandung bahan kasar yang bisa diraba.

\section{Uji Daya Lekat}

masker gel peel off ditimbang sebanyak $200 \mathrm{mg}$ diletakkan diatas object glass kemudian di tutup dengan object glass yang lain dan ditekan dengan beban $1 \mathrm{~kg}$ selama 5 menit, kemudian beban diambil setelah itu kedua object glass ditarik dengan beban $80 \mathrm{~g}$ dan dicatat waktu sampai keduanya bisa terlepas. Daya lekat yang baik adalah lebih dari 1 detik..

\section{Uji Waktu mengering}

Sebanyak 1 gram dari masing - masing formula sediaan ke punggung tangan dengan ukuran $7 \mathrm{~cm} \mathrm{x} 7 \mathrm{~cm}$, kemudian diliat dengan stopwatch waktu yang diperlukan oleh sediaan untuk mengering, yaitu waktu hingga sediaan membentuk lapisan film. Syarat waktu mengering dari sediaan masker gel peel-off adalah 15-30 menit.

\section{Uji Daya sebar}

Sebanyak 1 gram sediaan gel diletakkan di atas kaca berukuran $20 \quad$ x $20 \quad \mathrm{~cm}$. Selanjutnya ditutupi dengan mika dan digunakan pemberat diatasnya hingga bobot mencapai 125 gram dan diukur diameternya setelah 1 menit. Syarat dari uji daya sebar ini adalah $5-7 \mathrm{~cm}$.

\section{Pengukuran pH}

Dilakukan dengan cara memasukkan masker gel peel-off ke dalam wadah, lalu diukur pHnya dengan $\mathrm{pH}$ meter. $\mathrm{pH}$ sediaan harus disesuaikan dengan $\mathrm{pH}$ kulit 4,5-6,5.

\section{Pengukuran Viskositas}

Pengujian dilakukan dengan cara sebanyak 100 gram masker gel peel off diukur secara langsung dengan menggunakan alat Viskometer dengan spindle nomer 1. Viskositas dilihat pada skala dalam alat setelah tercapai kestabilan.

\section{Pengujian Aktivitas Antibakteri}

Ditimbang Nutrien broth sebanyak 0,4 gram, dilarutkan dalam $50 \mathrm{~mL}$ aqdest (8g/1000) menggunakan erlenmeyer. Dan disterilkan dengan autoclave pada suhu $121^{\circ} \mathrm{C}$ selama 1 jam (Andaryekti, 2015). Diambil larutan asam sulfat $1 \% 9,5 \mathrm{~mL}$ dicampurkan dengan larutan $\mathrm{BaCl}_{2} 1 \%$ 0,5 mL dalam tabung reaksi dan dikocok sampai homogen. Apabila kekeruhan suspensi bakteri uji sama dengan kekeruhan larutan standar, bearti konsentrasi suspense bakteri adalah $10^{8}$ $\mathrm{CFU} / \mathrm{mL}$. Kekeruhan ini dipakai sebagai standar kekeruhan suspense bakteri uji. (Arista, 2013). Diambil 1 ose bakteri Staphylococus aureus disuspensikan kedalam tabung yang berisi $2 \mathrm{~mL}$ media Nutrien Broth. Diinkubasi pada suhu 37 ${ }^{\circ} \mathrm{C}$ selama 24 jam.

Ditimbang Muller Hinton Agar (MHA) sebanyak 8,5 gram dimasukkan kedalam erlenmeyer, ditambah aquadest $250 \mathrm{~mL}$ (34 g/1000mL) dilarutkan dengan pemanasan di atas api bunsen. Lalu disterilkan dengan autoclave dengan suhu $121^{\circ} \mathrm{C}$ selama 60 menit. Dituang MHA ke dalam cawan petri dan dibiarkan memadat. Setelah media memadat, suspense bakteri diinokulasikan pada MHA dengan metode swab. Dibuat lubang sumuran sebanyak 6 lubang dengan menggunakan pencadang baja steril. Masing-masing sampel dipipet sebanyak $50 \mu \mathrm{l}$ kemudian diteteskan pada sumuran. Kemudian diinkubasi dalam inkubator pada suhu $37^{\circ} \mathrm{C}$ selama 24 jam. Dan diukur diameter daerah hambatan 
(zona jernih) menggunakan jangka Simplisia daun pacar air (Impatiens sorong.

balsamina L.) sebanyak 500 gram di larutkan dalam $3500 \mathrm{~mL}$ etanol 96\%

HASIL DAN PEMBAHASAN diekstrasi dengan cara maserasi selama 5 hari. Ekstrak yang didapat 48,096 gram.

Tabel 1. Hasil identifikasi kandungan kimia ekstrak daun pacar air

\begin{tabular}{ccc}
\hline Identifikasi & Pereaksi & Hasil \\
\hline Flavonoid & HCl pekat, serbuk Mg & + (positif) \\
Kuinon & NaOH 1N & + (positif) \\
Saponin & Aquadest & + (positif) \\
Bebas Etanol & Asam asetat, asam sulfat & - (negatif) \\
\hline
\end{tabular}

Berdasarkan penapisan fitokimia yang mengganggu integritas membran sel yang telah dilakukan diperoleh hasil bakteri ( Anderyekti et al., 2015 ). Dan ekstrak daun pacar air (Impatiens pada senyawa kuinon memiliki balsamina L.) positif mengandung mekanisme yakni menonaktifkan adhesin senyawa flavonoid, kuinon, dan saponin. dan enzim mikroba, serta mengikat asam Senyawa - senyawa inilah yang berperan amino secara irreversible. Saponin dalam memberikan efek antibakteri. bekerja sebagai antibakteri dengan Flavonoid bersifat antibakteri dengan mengganggu stabilitas membran sel membentuk senyawa kompleks terhadap bakteri sehingga menyebabkan sel protein dengan cara membentuk senyawa bakterilisis.

kompleks terhadap protein ekstraseluler

Tabel 2. Formulasi Sediaan Masker Gel Pell-Off

\begin{tabular}{cccc}
\hline Bahan & F 1 & F 2 & F 3 \\
& $(\%)$ & $(\%)$ & $(\%)$ \\
\hline Ekstrak daun pacar air & 8 & 8 & 8 \\
PVA & 6,5 & 6,75 & 2 \\
HPMC & 2,5 & 2,25 & 15 \\
Propilglikol & 15 & 15 & 2 \\
TEA & 2 & 2 & 100 \\
Aqua dest ad & 100 & 100 & \\
\hline
\end{tabular}


Hasil pengamatan organoleptis menunjukan bahwa sediaan masker gel peel-off berbentuk semi padat, coklat, berbau khas ekstrak dan homogen. Warna coklat dari masker gel peel-off ini dari warna ekstrak daun pacar air. Bau khas dari masker gel peel-off ekstrak daun pacar air ini adalah bau khas dari ekstrak daun pacar air itu sendiri karena konsentrasi dari zat aktif cukup tinggi dan pada formulasi masker gel peel-off ini tidak menggunakan penambahan pengaroma. Pada formulasi masker gel pel-off ekstrak daun pacar air semua sediaan homogen karena tidak terdapat partikel kasar pada masker gel peel-off.

Tabel 3. Hasil pemeriksaan karakterisistik masker gel peel-off ekstrak daun pacar air

\begin{tabular}{lccccc}
\hline Formulasi & pH & $\begin{array}{c}\text { Daya Lekat } \\
\text { (detik) }\end{array}$ & $\begin{array}{c}\text { Daya Sebar } \\
(\mathbf{c m})\end{array}$ & $\begin{array}{c}\text { Waktu } \\
\text { Mengering } \\
\text { (menit) }\end{array}$ & $\begin{array}{c}\text { Viskositas } \\
\text { (cpas) }\end{array}$ \\
\hline F1 & 5,1 & 12,13 & 5,8 & 28,48 & 3800 \\
F2 & 5,1 & 10,12 & 6,2 & 26,56 & 3300 \\
F3 & 5,2 & 9,07 & 6,85 & 21,68 & 1600 \\
\hline
\end{tabular}

F1: Kombinasi PVA:HPMC $(6,5: 2,5)$

F2: Kombinasi PVA:HPMC $(6,75: 2,25)$

F3: Kombinasi PVA:HPMC (7:2)

Pengukuran $\mathrm{pH}$ dilakukan untuk mengetahui apakah $\mathrm{pH}$ suatu sediaan agar sesuai dengan persyaratan $\mathrm{pH}$ yang ditetapkan berkisar antara 4,5-6,5. Untuk sediaan topikal yang akan digunakan pada kulit jika memiliki pH lebih kecil dari 4,5 dapat menimbulkan iritasi pada kulit sedangkan jika $\mathrm{pH}$ lebih besar dari 6,5 dapat menyebabkan kulit bersisik. Pada uji Anova pengukuran $\mathrm{pH}$ didapat sig > 0,05 yang dapat disimpulkan bahwa tidak ada perbedaan yang bermakna pada pengukuran $\mathrm{pH}$ sediaan masker gel peeloff.

Pengujian daya lekat dilakukan untuk mengetahui kemampuan sediaan masker gel peel-off bertahan dipermukaan kulit ketika dioleskan. Semakin besar nilai daya lekat maka semakin besar difusi obat karena ikat yang terjadi antara sediaan dengan kulit semakin lama. Meningkatnya konsentrasi HPMC mengakibatkan konsistensi gel yang kental, hal tersebut berkaitan dengan gaya antar atom pada sediaan. Semakin kental sediaan maka gaya antar atom semakin kuat sehingga sediaan melekat lebih lama. Dari uji statistik dengan anova untuk pengujian daya lekat diketahui signifikansi atau $p$ $0,001<0,05$. Hal ini menunjukan bahwa ada perbedaan yang bermakna pada pengujian daya lekat antara ketiga formulasi masker gel peel-off ekstrak daun pacar air.

Pengujian daya sebar dilakukan untuk mengetahui kemampuan penyebaran masker gel peel off saat diaplikasikan ke kulit. Masker gel pell-off yang baik membutuhkan waktu yang lebih sedikit untuk tersebar dan akan memiliki 
nilai daya sebar yang tinggi. Semakin besar daya sebar menggambarkan semakin baik luas penyebaran masker area dikulit yang diaplikasikan masker. Penurunan daya sebar terjadi melalui peningkatan ukuran unit molekul karena telah mengabsorbsi pelarut sehingga cairan tersebut tertahan dan meningkatkan tahanan untuk mengalir dan menyebar. Dari uji statistik dengan anova untuk pengujian daya sebar semua formulasi diketahui signifikansi atau p 0,002 <0,05. Hal ini menunjukan bahwa ada perbedaan yang bermakna pada pengujian daya sebar antara ketiga formulasi masker gel peeloff ekstrak daun pacar air.

$$
\text { Pengujian waktu sediaan }
$$
mengering bertujuan untuk mengetahui waktu yang diperlukan oleh masker gel peel off untuk membentuk lapisan film dan mengering setelah diaplikasikan ke kulit. . Konsentrasi PVA merupakan faktor terpenting yang berpengaruh terhadap kinerja pembentukan film dalam masker wajah peel off. Dari uji statistik dengan anova untuk pengujian waktu mengering semua formulasi diketahui signifikansi atau p 0,000 $<0,05$. Hal ini menunjukan bahwa ada perbedaan yang bermakna pada pengujian waktu mengering antara ketiga formulasi masker gel peel-off ekstrak daun pacar air.

Pengujian viskositas pada sediaan perlu dilakukan untuk menjamin menghasilkan masker gel peel-off yang optimal. Sediaan dengan viskositas terlalu rendah menyebabkan waktu kontak dengan kulit tidak cukup lama sehingga aktivitas bahan aktif tidak optimal, viskositas yang besar meningkatkan waktu retensi pada tempat aplikasi, tetapi juga menurunkan daya sebar. Peningkatan konsentrasi HPMC dapat meningkatkan serat polimer sehingga semakin banyak juga cairan yang tertahan dan terikat oleh agen pembentuk gel sehingga viskositas menjadi meningkat. Dari uji statistik dengan anova untuk pengujian viskositas semua formulasi diketahui signifikansi atau p 0,000 < 0,05. Hal ini menunjukan bahwa ada perbedaan yang bermakna pada pengujian viskositas antara ketiga formulasi masker gel peel-off ekstrak daun pacar air.

Tabel 4. Hasil pengujian aktivitas antibakteri

\begin{tabular}{ccccccc}
\hline & \multicolumn{6}{c}{ Aktivitas Antibakteri (mm) } \\
\cline { 2 - 7 } No & F1 & F2 & F3 & $\begin{array}{c}\text { Kontrol } \\
(+)\end{array}$ & $\begin{array}{c}\text { Kontrol } \\
(-)\end{array}$ & $\begin{array}{c}\text { Ekstrak } \\
\mathbf{8 \%}\end{array}$ \\
\hline $\begin{array}{c}\text { Rata- } \\
\text { Rata } \pm \\
\text { SD }\end{array}$ & $5,67 \pm 1,52$ & $7,67 \pm 1,52$ & $12 \pm 2$ & $17 \pm 2,64$ & 0 & $15 \pm 3,60$ \\
\hline
\end{tabular}

Pengujian antibakteri ini dilakukan dnegan menggunakan metode sumuran dengan media muller hinton agar (MHA). Pada pengujian aktivitas antibakteri menunjukan bahwa formulasi masker gel peel-off memiliki aktivitas antibakteri ditandai dengan terbentuknya zona hambat terhadap bakteri Staphylococcus aureus. Timbulnya zona hambat ini disebabkan karena senyawa aktif yang terkandung dalam basis gel berdifusi melalui media sehingga mampu menghambat pertumbuhan bakteri Staphylococcus aureus. Kontrol positif 
yang digunakan dalam pengujian anti bakteri ini adalah gel klindamisin phosphat 1,2\%. Dan kontrol negatif yang digunakan adalah basis masker gel peeloff tanpa ekstrak. Dari uji statistik dengan anova untuk pengujian aktivitas

\section{SIMPULAN}

Perbedaan kombinasi PVA dan HPMC dalam karakteristik sediaan masker gel peel-off ekstrak daun pacar air (Impatiens balsamina Linn.) tidak berngaruh dalam pengukuran $\mathrm{pH}$ dan uji daya sebar tetapi

\section{DAFTAR PUSTAKA}

Adfa, Morina.,2008. Senyawa Antibakteri Dari Daun Pacar Air (Impatiens Balsamina Linn.). Jurnal Gradien Vol.4 No.1

Anggraini, Dne., Noveri Rahmawati dan Siti Hafsah. 2013. Formulasi Gel Antijerawat dari Ekstrak Etil Asetat Gambir. Jurnal Penelitian Farmasi Indonesia 1(2) : 62-66 ISSN 2302$187 \mathrm{X}$

Arista, Yuni ., Kumesan, Paulina V. Y. Yamlean., Hamidah S. Supriati. 2013. Formulasi dan Uji Aktivitas Gel Anti Jerawat Ekstrak Umbi Bakun (Crinum Asiaticum L) Terhadap Bakteri Staphylococcus Aureus Secara In Vitro. Jurnal Ilmiah Farmasi - UNSRAT Vol. 2 No. 02

Anzini, NIA., Indri Kusharyanti dan Siti Nani Nurbaeti.2014. Uji Toksisitas Akut Fraksi Etil Asetat Batang dan Daun Pacar Air (Impatiens antibakteri semua formulasi diketahui signifikansi atau p 0,001<0,05. Hal ini menunjukan bahwa ada perbedaan yang bermakna pada pengujian aktivitas antibakteri antara ketiga formulasi masker gel peel-off ekstrak daun pacar air.

berpengaruh pada uji daya lekat, uji waktu mengering dan uji viskositas. Sediaan gel peel-of ekstrak daun pacar air (Impatiens balsamina Linn.) mempunyai aktivitas antibakteri terhadap bakteri Staphylococcus aureus.

balsamina Linn) Terhadap Tikus Putih Betina Galur Sprague Dawley. J. Trop. Pharm. Chem. 2014. Vol 2. No. 4

Andaryekti, Rufi., Mufrod dan Siti Munisih. 2015. Pengaruh Basis Gel Sediaan Masker Ekstrak Daun Teh Hijau (Camellia sinensis linn) Pada Karakteristik Fisik dan Aktivitas Bakteri Staphylococcus Aureus ATCC 25923. Majalah Farmaseutik. Beringhs, A.O., M.R. Julia, K.S. Hellen, M.B. Rosane, and S. Diva. 2013. Green clay and aloe vera peei-off facial mask: respone surface methodology applied to the formulation design. AAPS Pharm Sci Tech. 14 (1): 445-455.

Cushnie, T.P., Lamb, A.J.2005. Antimicrobial activity of flavonoids. International Journal of Antimicrobial Agents, 26(5), 343356 
Garg, A., A. Deepika, S. Garg, and A. K.

Singla. 2002. Spreading of Semisolid Formulation. USA: Pharmaceutical Tecnology. Pp. 84104. I

Harry, Ralph G. 2000. Harry Cosmeticology. New York : Chemical Publishing

Ismarani, Diah., Liza Pratiwi, Indri Kusharyanti.2014. Formulasi Gel Pacar Air (Impatiens balsamina Linn.) terhadap Propionibacterium acnes dan Staphylococcus epidermidis. Pharm Sci Res ISSN 2407-2354

Kristanti, Alfinda Novi., Nanik Siti Aminah., Mulyadi Tanjung., Bambang Kurniadi.2008. Buku Ajar Fitokimia. Surabaya : Universitas Airlangga-Press

Lestari, P.M., Sutyasningsih, R. B. and Ruhimat. 2013. The Influence of Increase Concentration Polivinil Alcohol (PVA) As a Gelling Agent On Physical Properties of The PeelOff Gel Of Pineapple Juice (Ananas comosus L.). Asian Societies of Cosmetic Scientists Conference. P. 127

Niyogi, P., Raju, N. J., Reddy, P. G., \& Rao, B. G. 2012. Formulation an Evaluation of Antiinflamatory Activity of Solanum pubescens Wild
Extract Gel on Albino Wistar Rats. International Journal of Pharmacy.2.(3): 484-490.

Panichayupakaranant, P. 2001. 14. Napthoquinone Formation in Impatiens balsamina Cell Cultures. Pharmaceutical Biology, 39(4), 293296

Rowe, R. C., P. J. Sheskey, and M. E. Quinn. 2009. Handbook of Pharmaceutical Exipients. Six Edition. London: Pharmaceutical Press.

Rahmawanty, D., Yulianti, N., dan Fitriana, M. 2015. Formulasi dan Evaluasi Masker Wajah Peel Off Mengandung Kuersetin Dengan Variasi Konsentrasi Gelatin dan Gliserin. Media Farmasi.12. (1) : 17-32.

Sakunphueak, A., Panichayupakaranant, 15. P. 2012. Comparison of antimicrobial activities of naphtaquinones from Impatiens balsamina. Natural Product Research, 26(12),1119-1124

Samaranayake L. 2012. Essential microbiology for dentistry 4th ed. China: Elsevier

Tranggono, Retno Iswari, Latifah, Fatmah. 2007. Buku Pegangan Ilmu Pengetahuan Kosmetik. Jakarta : PT. Gramedia Pustaka Utama 